\title{
Genotypic and Environmental Variations in Grain Cadmium and Arsenic Concentrations Among a Panel of High Yielding Rice Cultivars
}

\author{
Guilan Duan ${ }^{1 \dagger}$, Guosheng Shao ${ }^{2 \dagger}$, Zhong Tang ${ }^{3 \dagger}$, Hongping Chen ${ }^{3}$, Boxun Wang ${ }^{1}$, Zhu Tang ${ }^{3}$, Yuping Yang ${ }^{1}$, \\ Yuechuan Liu ${ }^{4}$ and Fang-Jie Zhao ${ }^{3^{*}}$ (D)
}

\begin{abstract}
Background: Rice is a major dietary source of cadmium (Cd) and arsenic (As) for populations consuming rice as the staple food. Excessive $\mathrm{Cd}$ and As accumulation in rice grain is of great concern worldwide, especially in South China where soil contamination with heavy metals and metalloids is widespread. It is important to reduce $\mathrm{Cd}$ and As accumulation in rice grain through selection and breeding of cultivars accumulating low levels of $\mathrm{Cd}$ or As.

Results: To assess the genetic and environmental variations in the concentrations of $\mathrm{Cd}$ and As in rice grains, 471 locally adapted high-yielding rice cultivars were grown at three moderately contaminated sites in South China for two years. Cadmium and As concentrations in brown rice varied by $10-32$ and $2.5-4$ fold, respectively. Genotype $(G)$, environment $(E)$ and $G \times E$ interactions were highly significant factors explaining the variations. Brown rice $\mathrm{Cd}$ concentration was found to correlate positively with the heading date among different cultivars, whereas As concentration and heading date correlated negatively. There was a significant and negative correlation between grain $\mathrm{Cd}$ and As concentrations.

Conclusions: Eight and 6 rice cultivars were identified as stable low accumulators of $\mathrm{Cd}$ and As, respectively, based on the multiple site and season trials. These cultivars are likely to be compliant with the grain $\mathrm{Cd}$ or As limits of the Chinese Food Safety Standards when grown in moderately contaminated paddy soils in South China.
\end{abstract}

Keywords: Arsenic, Cadmium, Food Safety, Genotype, Rice

\section{Background}

Cadmium (Cd) and arsenic (As) are both classified as a Group-1 carcinogen by the International Agency for Research on Cancer (IARC, 1993) and the National Toxicology Program (NTP 2000). Arsenic and Cd rank first and seventh, respectively, on the Agency for Toxic Substances and Disease Registry Priority List of Hazardous Substances (www.atsdr.cdc.gov/SPL/index.html). Longterm exposure to high levels of $\mathrm{Cd}$ may lead to a variety of health problems, including Itai-Itai disease (Murata et al.,

\footnotetext{
* Correspondence: fangjie.zhao@njau.edu.cn

${ }^{\dagger}$ Equal contributors

${ }^{3}$ State Key Laboratory of Crop Genetics and Germplasm Enhancement, College of Resources and Environmental Sciences, Nanjing Agricultural University, Nanjing 210095, China

Full list of author information is available at the end of the article
}

1970; Bhattacharyya et al., 1992; Satarug and Moore, 2004), whilst long-term exposure to high levels of As may hurt the nervous system, damage blood vessels or lead to cancer of humans (Chen et al., 1986; Smith et al., 2000).

Cadmium and As are ubiquitous in the environment due to natural pedogenic processes, such as weathering of minerals, and to anthropogenic activities, such as mining, waste disposal, applications of fertilizers and agrochemicals (Nordstrom, 2002; Liu et al., 2005). A recent nationwide soil survey in China showed that 7 and $2.7 \%$ of the soil samples were contaminated with $\mathrm{Cd}$ and $\mathrm{As}$, respectively (MEP, 2014). There is also evidence that average soil $\mathrm{Cd}$ concentrations have increased considerably over the last three decades, by over $50 \%$ in the coastal and southwest regions (Zhao et al., 2015). 
Compared with other heavy metals, $\mathrm{Cd}$ has a relatively high bioavailability in soil and can be readily taken up by plants (Bolan et al. 2003; Clemens \& Ma, 2016). Substantial proportions of rice grain produced in some areas in southern China were found to exceed the Chinese Food Hygiene Standards for $\mathrm{Cd}\left(0.2 \mathrm{mg} \mathrm{kg}^{-1}\right)$ (Zhen et al., 2008; Zhu et al., 2008; GB2762, 2012). For example, $\mathrm{Du}$ et al. (2013) showed that $60 \%$ of the rice samples collected from a county in northern Hunan province exceed the $0.2 \mathrm{mg} \mathrm{Cd} \mathrm{kg}^{-1}$ limit, with $11 \%$ of the samples

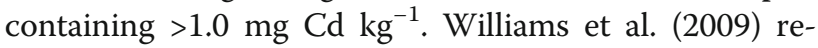
ported that $65 \%$ of rice grain samples from paddy fields impacted by mining activities in Hunan exceeded the $\mathrm{Cd}$ limit. Zhu et al. (2016) showed that $76 \%$ of rice grain samples from central-eastern Hunan province exceeded the $\mathrm{Cd}$ limit, with the maximum $\mathrm{Cd}$ concentration up to $4.8 \mathrm{mg} \mathrm{kg}^{-1}$. A number of factors likely contribute to the elevated $\mathrm{Cd}$ levels in rice grain in southern China, including contamination of soil and irrigation water, soil acidification and cultivation of rice cultivars with high Cd accumulation (Zhao et al. 2015; Zhu et al. 2016). Paddy rice is also efficient at accumulating As (Williams et al. 2007). This is because the anaerobic conditions in flooded paddy soil are conducive to the mobilization of arsenite (Xu et al. 2008; Arao et al., 2009), which is subsequently taken up by the highly expressed silicon uptake pathway in rice roots (Ma et al. 2008; Zhao et al. 2010). Arsenic accumulation in rice grain is further elevated by contamination of paddy soil or irrigation water (Zhu et al. 2008; Dittmar et al. 2010). For example, Zhu et al. (2008) and Williams et al. (2009) showed that 50$65 \%$ of the rice grain samples from mining-impacted paddy fields in Hunan province exceeded the Chinese Food Hygiene Standards for As of $0.15 \mathrm{mg} \mathrm{kg}^{-1}$ inorganic As (GB 2715-2005, which has been superseded by GB2762 (2012) with the limit of inorganic As raised to $\left.0.2 \mathrm{mg} \mathrm{kg}^{-1}\right)$.

Rice consumption constitutes a major source of dietary intake of inorganic As and $\mathrm{Cd}$ for populations whose staple food is rice (Tsukahara et al., 2003; Mondal \& Polya, 2008; Signes-Pastor et al., 2016). Li et al. (2011) showed that rice contributes up to 50 and $60 \%$ of the total dietary inorganic As for the Bangladeshi and Chinese populations, respectively. For $\mathrm{Cd}$, rice and its products also contribute up to $50 \%$ of the ingested $\mathrm{Cd}$ for most Asian populations (Tsukahara et al., 2003). Therefore, reducing Cd and As accumulation in rice is important for food safety and public health.

Depending on the soil conditions and the characteristics of the contaminant, a number of mitigation measures may be employed to reduce $\mathrm{Cd}$ and As accumulation in rice grains (Zhao et al. 2015; Chaney et al., 2016). These include liming of acidic soils, paddy water management, selection and breeding of rice cultivars with low accumulation of the contaminants, and phytoremediation. Liming is effective in decreasing $\mathrm{Cd}$ bioavailability in acidic soils and Cd uptake by rice (Bolan et al., 2003; Zhu et al. 2016), but not for As. Paddy water management can produce opposite effects on $\mathrm{Cd}$ and As accumulation. Maintaining flooded paddy conditions decreases $\mathrm{Cd}$ accumulation, but increases As accumulation in rice grains ( $\mathrm{Li}$ et al. 2009; Arao et al. 2009; Hu et al. 2013). Phytoremdiation has been tested in small scale field trials (Murakami et al., 2009; Mandal et al., 2012; Deng et al., 2015), but its applicability to cleaning up large areas of contaminated paddy soils remains uncertain. Selection of cultivars accumulating low levels of $\mathrm{Cd}$ or As represents a feasible and practical option because there exist large genetic variations among rice cultivars in the accumulation of these metals and metalloids in grain (Norton et al., 2012a; Duan et al., 2012; Kuramata et al., 2013; Pinson et al. 2015). For example, Norton et al. (2012a) conducted six field trials in Bangladesh, China and USA over 2 years and found there was a 3-34 fold variation in grain As concentration among $c .300$ rice accessions (Norton et al., 2012a). Pinson et al. (2015) reported 40.7 and 12.1-fold variations for grain $\mathrm{Cd}$ and As concentrations, respectively, among 1763 rice accessions of diverse geographic and genetic origin when grown under flooded paddy conditions. Pinson et al. (2015) also found that $\mathrm{Cd}$ and As variation had a significant genetic basis, with broad sense heritability varying from 0.24 to 0.63 for $\mathrm{Cd}$ and from 0.57 to 0.64 for As, respectively. These results indicate substantial and heritable genetic variability among rice varieties or germplasm that can be employed to reduce $\mathrm{Cd}$ and As accumulation in rice grain.

However, most of the previous screening studies used rice germplasm resources, and the accessions they found to have low levels of As or Cd accumulation may not be suitable to the growth conditions in South China. Therefore, these low accumulating accessions cannot be immediately usable in South China, where the problem of heavy metal and metalloid contamination is serious. In the present study, variations in grain $\mathrm{Cd}$ and $\mathrm{As}$ accumulation among 471 high yielding rice cultivars that are widely grown in southern China were investigated in two years at multiple sites with moderate levels of $\mathrm{Cd}$ contamination in Southern China. A number of cultivars with low $\mathrm{Cd}$ or As accumulation across multiple environments were selected. The relationships between grain $\mathrm{Cd}$ and As concentrations and heading date were examined.

\section{Results}

Field experiments were conducted at three sites. Soils at all sites are acidic (Table 1). Two of the sites (Youxian and Fuyang) contain moderate levels of $\mathrm{Cd}\left(0.4-0.5 \mathrm{mg} \mathrm{kg}^{-1}\right)$ (Table 1), both exceeding the $\mathrm{Cd}$ limit of the Chinese soil 
Table $1 \mathrm{pH}$ and heavy metal concentrations in soils at the experimental sites

\begin{tabular}{|c|c|c|c|c|c|c|}
\hline Site & $\mathrm{pH}$ & $\begin{array}{l}\text { As } \\
\left(\mathrm{mg} \mathrm{kg}^{-1}\right)\end{array}$ & $\begin{array}{l}\mathrm{Cd} \\
\left(\mathrm{mg} \mathrm{kg}^{-1}\right)\end{array}$ & $\begin{array}{l}\mathrm{Cu} \\
\left(\mathrm{mg} \mathrm{kg}^{-1}\right)\end{array}$ & $\begin{array}{l}\mathrm{Zn} \\
\left.(\mathrm{mg} \mathrm{kg})^{-1}\right)\end{array}$ & $\begin{array}{l}\mathrm{Pb} \\
\left(\mathrm{mg} \mathrm{kg}^{-1}\right)\end{array}$ \\
\hline Youxian (2014) & 4.88 & 22.5 & 0.55 & 28.6 & 137.4 & 42.3 \\
\hline Youxian (2015) & 5.19 & 17.4 & 0.46 & 29.9 & 100.7 & 35.4 \\
\hline Fuyang & 5.64 & 12.2 & 0.39 & 28.3 & 120.6 & 36.4 \\
\hline Xiantan & 4.87 & 19.4 & 1.40 & 27.4 & 125.3 & 39.9 \\
\hline Standards* & & 30 & 0.3 & 50 & 200 & 250 \\
\hline
\end{tabular}

${ }^{*}$ National Environmental Protection Bureau Environmental quality standard for soils GB 15618, 1995

environmental quality standard $\left(0.3 \mathrm{mg} \mathrm{kg}^{-1}\right.$ for soils with $\mathrm{pH}<7.5$; GB 15618, 1995). The other site (Xiangtan) contains a higher level of $\mathrm{Cd}\left(1.4 \mathrm{mg} \mathrm{kg}^{-1}\right)$ than the other sites. The total soil As concentrations were higher than the background level $\left(<10 \mathrm{mg} \mathrm{kg}^{-1}\right)$, but still below the As limit of the Chinese soil environmental quality standard (30 $\mathrm{mg} \mathrm{kg}^{-1}$ for paddy soils) (GB 15618, 1995) (Table 1). In 2014, 471 rice cultivars widely grown in Southern China were grown at Youxian and Fuyang. Based on the results of the trials in 2014, 63 rice cultivars were selected for further trials at three sites in 2015.

\section{Cadmium Concentration in Rice Grain}

Out of the 471 cultivars (Additional file 1: Table S1) planted in 2014, 466 and 462 cultivars grew to maturity and were harvested successfully at the experimental sites at Youxian, Hunan Province and Fuyang, Zhejiang Province, respectively. Cadmium concentration in rice grain (i.e. unpolished brown rice) harvested from Youxian and Fuyang ranged from 0.03 to $0.86 \mathrm{mg} \mathrm{kg}^{-1}$ and from 0.06 to $0.58 \mathrm{mg} \mathrm{kg}^{-1}$, respectively (Fig. 1a), representing about 32 and 10 fold variation among the harvested cultivars. At the Youxian and Fuyang sites, 83 and 34\%, respectively, of the harvested cultivars exceeded the Chinese
Food Hygiene Standards (GB2762 2012, $0.2 \mathrm{mg} \mathrm{kg}^{-1} \mathrm{Cd}$ in the grain).

Based on the results of 2014, 52 cultivars were further tested in 2015, including 44 low $\mathrm{Cd}, 3$ high $\mathrm{Cd}$ and 5 low As rice cultivars. Additionally, 11 cultivars with late heading date were also included. Of the 63 cultivars planted in 2015, 62, 63 and 61 cultivars were successfully harvested from the Youxian, Fuyang and Xiangtan (Hunan Province) sites, respectively. Cadmium concentration in rice grain ranged from 0.02 to $0.24 \mathrm{mg} \mathrm{kg}^{-1}$, from 0.08 to $0.68 \mathrm{mg} \mathrm{kg}^{-1}$, and from 0.14 to $1.17 \mathrm{mg} \mathrm{kg}^{-1}$ at Youxian, Fuyang and Xiangtan, respectively (Fig. 1b). The variations among different cultivars were 10,9 and 8 fold, respectively, with 2, 52 and $80 \%$ of the cultivars harvested exceeding the grain $\mathrm{Cd}$ limit. The much lower percentage of $\mathrm{Cd}$ exceedance in 2015 at the Youxian site, compared with the 2014 results, could be explained by the selection of 44 low Cd cultivars, a slightly lower soil Cd concentration and a higher $\mathrm{pH}$ in the field used in 2015 (Table 1), and a wetter season in 2015 than 2014 which could have resulted in a lower Cd bioavailability.

For each year, two-way ANOVA analysis on the pooled data from different sites indicated that grain Cd concentration was significantly affected by genotype (G),
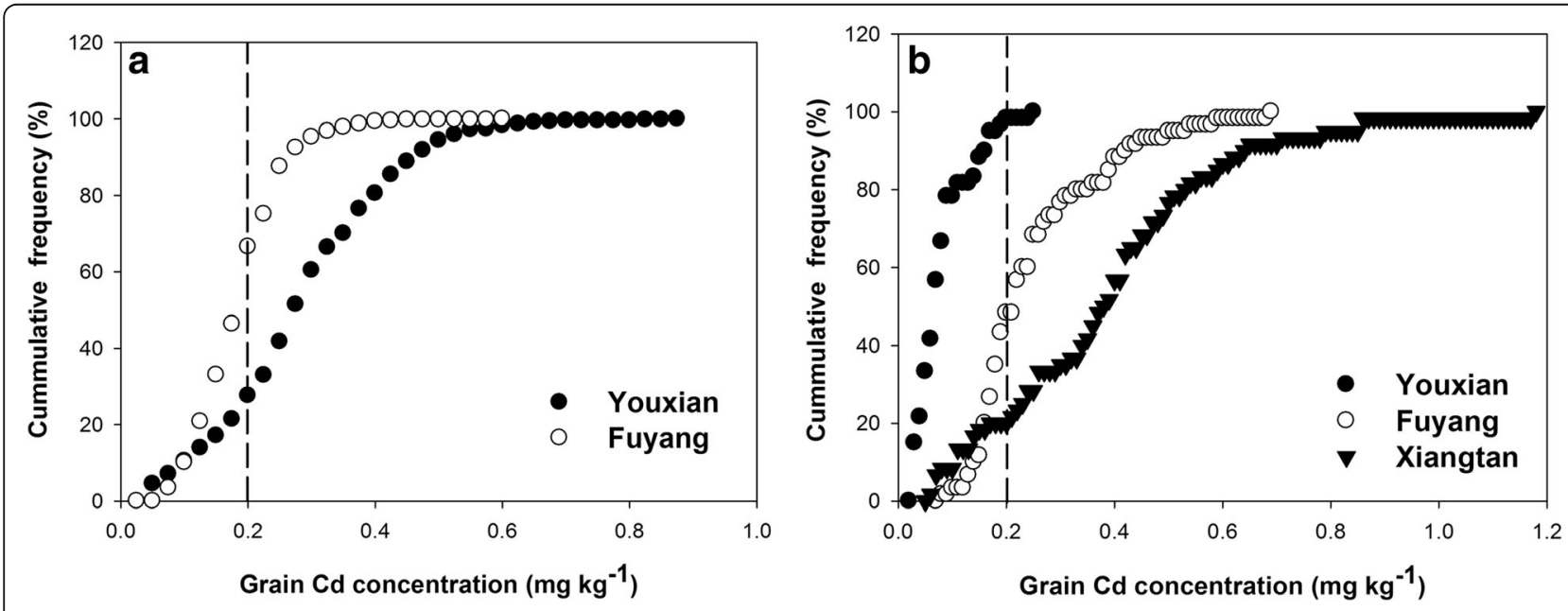

Fig. 1 Cumulative frequency of Cd concentration in brown rice harvested at two sites in 2014 (a) and three sites 2015 (b). The vertical dash line indicates Chinese Food Hygiene Standards for rice Cd concentration $\left(0.2 \mathrm{mg} \mathrm{kg}^{-1}\right)$ 
Table 2 Two-way ANOVA analysis of grain Cd and As concentrations in two sites in 2014 and three sites in 2015

\begin{tabular}{|c|c|c|c|c|c|c|c|c|}
\hline & Variation & SS & $d f$ & MS & $F^{a}$ & F crit & $P$-value & SSE/SST (\%) \\
\hline \multicolumn{9}{|l|}{$\mathrm{Cd}$} \\
\hline \multirow[t]{4}{*}{2014} & Genotype (G) & 20586173 & 455 & 45244 & 20.00 & 1.13 & $<0.0001$ & 48.46 \\
\hline & Environment (E) & 6920449 & 1 & 6920449 & 3059.48 & 3.85 & $<0.0001$ & 16.29 \\
\hline & $G \times E$ & 10850810 & 455 & 23848 & 10.54 & 1.13 & $<0.0001$ & 25.54 \\
\hline & Error & 4125834 & 1824 & 2262 & & & & \\
\hline \multirow[t]{4}{*}{2015} & Genotype (G) & 6047463 & 59 & 102499 & 123.55 & 1.36 & $<0.0001$ & 29.65 \\
\hline & Environment (E) & 8285986 & 2 & 4142993 & 4994.02 & 3.02 & $<0.0001$ & 40.62 \\
\hline & $\mathrm{G} \times \mathrm{E}$ & 5767217 & 118 & 48875 & 58.91 & 1.27 & $<0.0001$ & 28.27 \\
\hline & Error & 298653 & 360 & 830 & & & & \\
\hline \multicolumn{9}{|l|}{ As } \\
\hline \multirow[t]{4}{*}{2014} & Genotype (G) & 3579026 & 455 & 7866 & 6.33 & 1.13 & $<0.0001$ & 38.24 \\
\hline & Environment (E) & 1169753 & 1 & 1169753 & 941.51 & 3.85 & $<0.0001$ & 12.50 \\
\hline & $G \times E$ & 2344688 & 455 & 5153 & 4.15 & 1.13 & $<0.0001$ & 25.05 \\
\hline & Error & 2266179 & 1824 & 1242 & & & & \\
\hline \multirow[t]{4}{*}{2015} & Genotype (G) & 1025771.997 & 59 & 17386 & 42.94 & 1.36 & $<0.0001$ & 31.05 \\
\hline & Environment (E) & 1096363.439 & 2 & 548182 & 1353.85 & 3.02 & $<0.0001$ & 33.19 \\
\hline & $G \times E$ & 1035829.127 & 118 & 8778 & 21.68 & 1.27 & $<0.0001$ & 31.35 \\
\hline & Error & 145765.79 & 360 & 405 & & & & \\
\hline
\end{tabular}

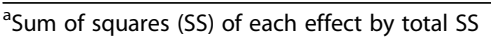

environment $(\mathrm{E})$, and $\mathrm{G} \times \mathrm{E}$ interactions (Table 2). Genotype, $\mathrm{E}$ and $\mathrm{G} \times \mathrm{E}$ accounted for 48,16 , and $26 \%$, respectively, of the total variation in 2014. The corresponding percentages in 2015 were 30,41 and $28 \%$, respectively. The higher contribution from G in 2014 than in 2015 could be explained by the much larger number of cultivars grown in the first year. In contrast, the 2015 trials included one additional site with a relatively higher level of soil $\mathrm{Cd}$, thus resulting in a higher percentage of contribution from $\mathrm{E}$ to the total variation. In both years, the contribution of $\mathrm{G} \times \mathrm{E}$ interactions to the total variation was similar.

\section{Stability of Grain Cd Concentration Across Sites and Seasons}

Correlation analysis was used to assess the stability of grain $\mathrm{Cd}$ concentration of rice cultivars across sites and years. Among the 456 common cultivars between Youxian and Fuyang in 2014, Cd concentration in brown rice correlated significantly $(r=0.55, P<0.0001)$ (Fig. 2a, Additional file 1: Table S2). In 2015, there were 60 common cultivars harvested from the three sites. Significant correlations were found between each two of the three sites (Fig. 2b, Additional file 1: Table S2). The correlation was stronger between Youxian and Fuyang $(r=0.75, P<$
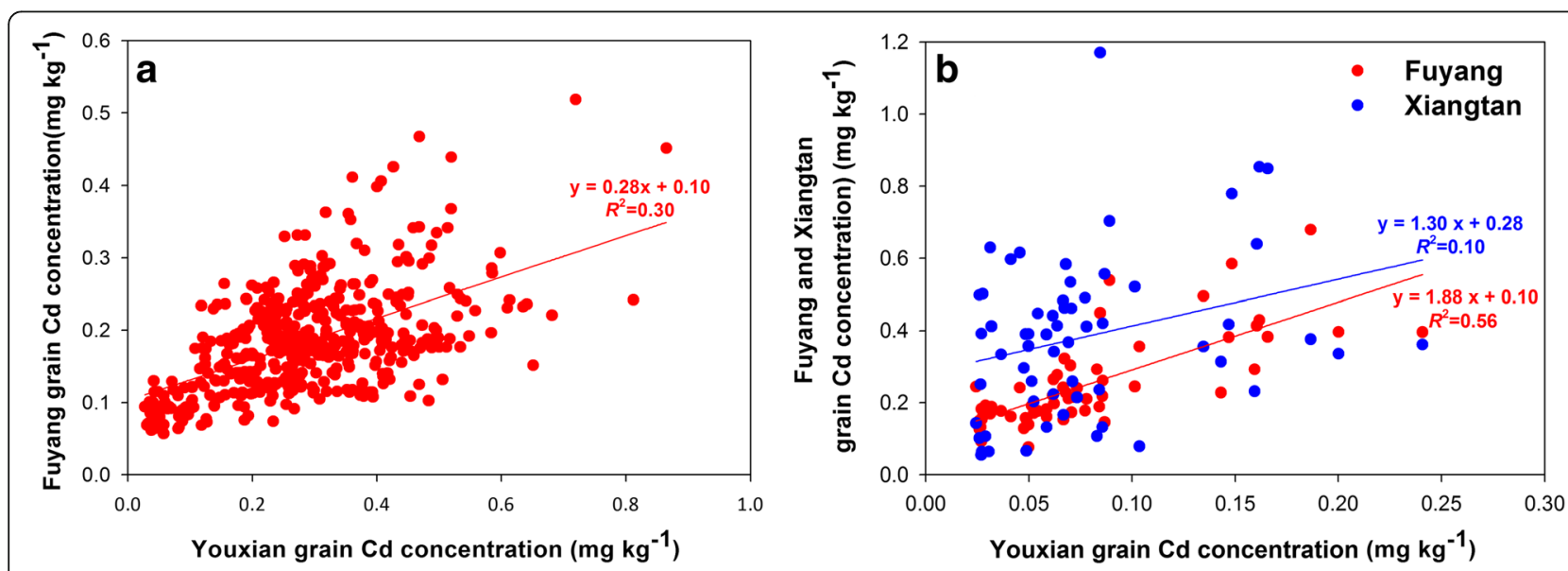

Fig. 2 Correlation between grain Cd concentrations of the common cultivars grown at different sites in 2014 (a) and 2015 (b) 
0.0001) than between either of these two sites with the high Cd site Xiangtan $(r=0.31-0.44, P<0.001)$.

Among the 52 common cultivars harvested in the two years, There were significant correlations in grain $\mathrm{Cd}$ concentration between 2014 and 2015 (Youxian, $r=0.81$, $P<0.0001$; Fuyang, $r=0.59, P<0.0001)$. Furthermore, the low Cd cultivars selected based on the 2014 data also exhibited low Cd accumulation again in 2015.

\section{Arsenic Concentration in Rice Grain}

In 2014, total As concentration in brown rice ranged from 0.11 to $0.44 \mathrm{mg} \mathrm{kg}^{-1}$ and from 0.17 to $0.42 \mathrm{mg} \mathrm{kg}^{-1}$ at Youxian and Fuyang, respectively (Fig. 3a), representing 4 and 2.5-fold variation, respectively. According to the study of Zhu et al. (2008), the mean ratio of inorganic As to total As in brown rice produced in South China is 0.61 . Using this ratio, the estimated concentration of inorganic As in brown rice ranged from 0.07 to $0.27 \mathrm{mg} \mathrm{kg}^{-1}$ and from 0.10 to $0.26 \mathrm{mg} \mathrm{kg}^{-1}$ at Youxian and Fuyang, respectively. Based on this estimation, from Youxian and Fuyang site, 8 and $4 \%$ cultivars, respectively, exceeded the current Chinese Food Hygiene Standards $\left(0.2 \mathrm{mg} \mathrm{kg}^{-1}\right.$ inorganic As) (GB2762, 2012). The range of grain As concentration was similar between the two sites despite a 1.8 fold difference in the soil total As concentration, suggesting similar bioavailability of As in the two soils.

In 2015, total As concentration in brown rice ranged from 0.15 to $0.36 \mathrm{mg} \mathrm{kg}^{-1}$ at Youxian, from 0.07 to $0.50 \mathrm{mg} \mathrm{kg}{ }^{-1}$ at Fuyang, and from 0.13 to $0.27 \mathrm{mg} \mathrm{kg}^{-1}$ at Xiangtan, respectively (Fig. 3b). The variations were 2 7 folds among the three sites. The estimated concentrations of inorganic As in all cultivars grown at Xiangtan were below the limit, whereas 5 and 22\% rice cultivars grown at Youxian and Fuyang, respectively, exceeded the limit.

Two-way ANOVA showed that As concentration in brown rice was significantly affected by genotype (G), environment $(E)$, and $G \times E$ interactions (Table 2). Environment explained 13 and $33 \%$ of the total variation in 2014 and 2015, respectively, whilst cultivars explained 38 and $31 \%$ of the total variation in the two respective years. Between 25 and $31 \%$ of the total variation could be explained by $\mathrm{G} \times \mathrm{E}$ interactions.

Stability of Grain As Concentration Across Sites and Seasons There were significant correlations in grain As concentration among the common cultivars between the Youxian and Fuyang sites in 2014 $(r=0.32, P<0.0001)$ (Fig. 4a, Additional file 1: Table S2), and between each two of the three sites in $2015(r=0.45-0.51, P<0.001$, Fig. 4a, Additional file 1: Table S2).

Comparing the years 2014 and 2015, there were also significant correlations in grain As concentration between the two years at each site (Youxian, $r=0.60, P<$ 0.0001 ; Fuyang, $r=0.73, P<0.0001$ ). Five cultivars selected as low As cultivars according to the 2014 trials also exhibited low As accumulation in 2015.

\section{The Relationship Between Straw and Grain Cd Concentrations}

Straw samples from Youxian in 2014 and Fuyang in 2015 were collected and analyzed for $\mathrm{Cd}$ concentration. In both trials, there was a strong linear relationship between grain and straw $\mathrm{Cd}$ concentrations (Youxian, $r=$ $0.78, P<0.0001, \mathrm{n}=466$, Fig. 5a; Fuyang, $r=0.85, P<$ $0.0001, n=64$; Fig. $5 \mathrm{~b}$ ). The slope of the regression was 0.13 and 0.21 in the two respective trials, which
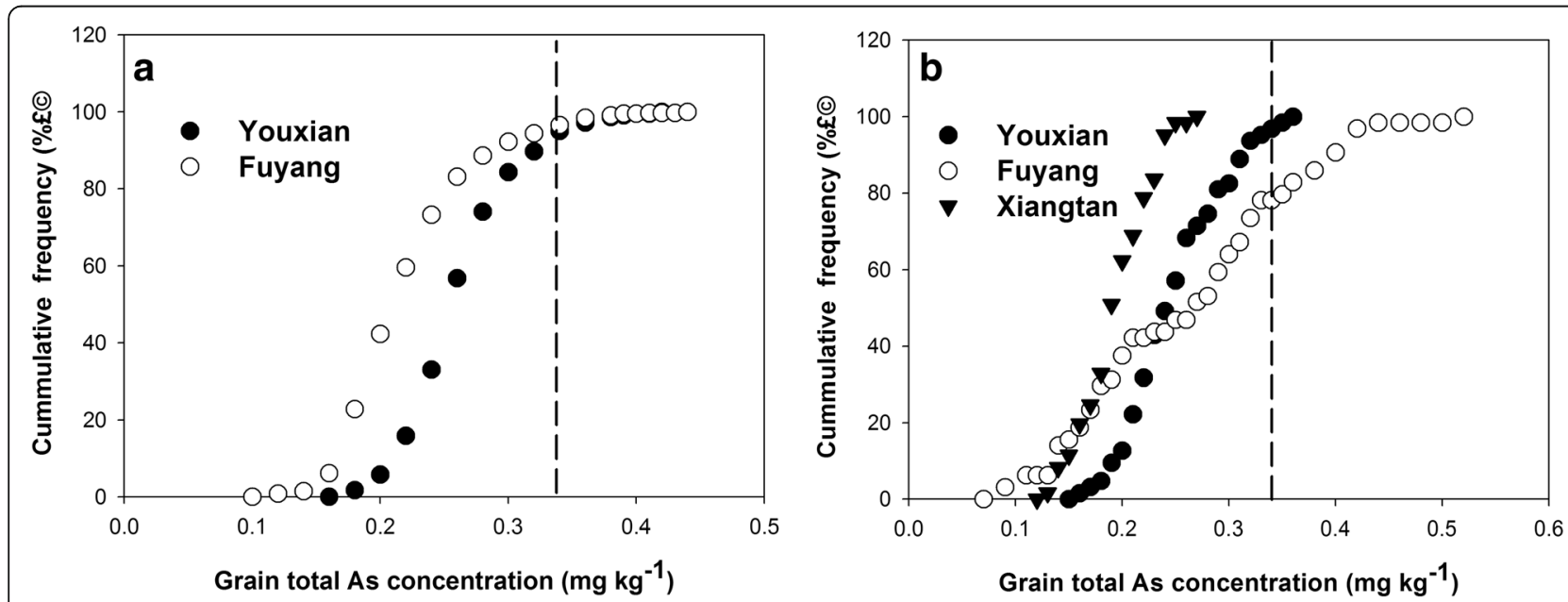

Fig. 3 Cumulative distribution of As concentration in brown rice harvested at different sites in 2014 (a) and 2015 (b). The vertical dash line indicates Chinese Food Hygiene Standards for rice As concentration $\left(0.2 \mathrm{mg} \mathrm{kg}^{-1}\right.$ inorganic As, equivalent to $0.33 \mathrm{mg} \mathrm{kg}^{-1}$ total As according to the mean ratio of inorganic As to total As of 0.61) 

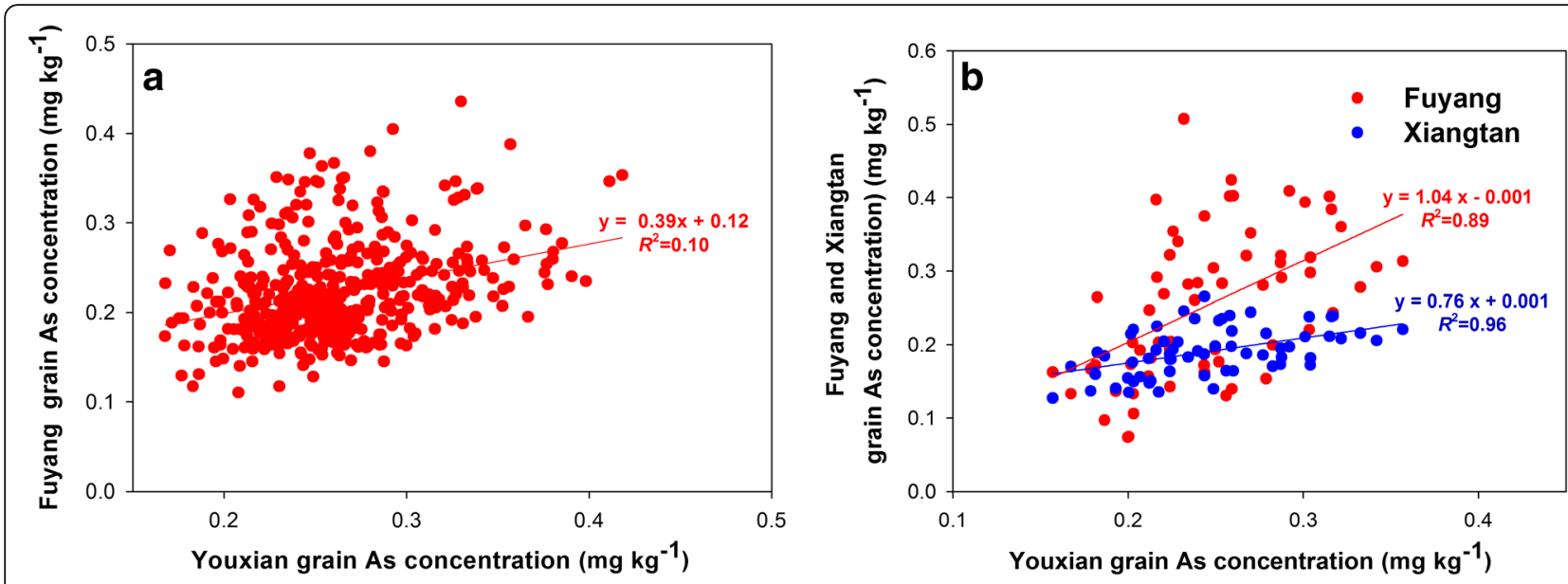

Fig. 4 Correlation between grain As concentrations of the common cultivars grown at different sites in 2014 (a) and 2015 (b)

represents the mean translocation factor of $\mathrm{Cd}$ from the straw to the grain. Despite the strong linear relationship between grain and straw $\mathrm{Cd}$ concentrations, the ratio of brown $\mathrm{Cd}$ to straw $\mathrm{Cd}$ exhibited substantial genotypic variation, ranging from 0.03 to 0.42 among the 466 cultivars in the Youxian trial and from 0.008 to 0.23 among the 64 cultivars in the Fuyang trial.

Straw samples from Fuyang in 2015 were also analyzed for As concentration. There was a strong linear relationship between grain and straw As concentrations, with the slope of the regression being 0.04 $(r=0.82, P<$ $0.0001, n=64$; Fig. 5c). The slope was much lower than that for $\mathrm{Cd}$, indicating a lower translocation of As from the straw to the grain than $\mathrm{Cd}$. There was approximately 3 fold variation in the ratio of brown As to straw As $(0.022-0.064)$ among the 64 cultivars.

\section{Grain Yield and the Correlations With As or Cd Concentration in Rice Grain}

Grain yield of each cultivar was estimated in the Youxian trial in 2015. Among the 64 cultivars, grain yield ranged from 6018 to $10186 \mathrm{~kg} \mathrm{ha}^{-1}$. There was a significant and positive correlation between grain yield and grain $\mathrm{Cd}$ concentration ( $r=0.49, P<0.0001, n=64$; Additional file 2: Figure S1), but a negative correlation between grain yield and grain As concentration $(r=0.33, P=0.008, n=64$; Additional file 2: Figure S1).

\section{Correlations Between Grain Cd and As Concentrations and the Heading Time}

The days from germination to full heading varied from 68 to 136 days among the cultivars harvested in 2014 . Cadmium concentration in rice grain was found to correlate significantly and positively with the heading time at both Youxian $(r=0.64, P<0.0001)$ and Fuyang $(r=0.45, P<0.0001)$ (Fig. 6a, Additional file 1: Table S3).
Among the cultivars harvested in 2015, there were also significant correlations between the heading time (70 - 135 days) and grain $\mathrm{Cd}$ concentration at all three sites $(r=0.58-0.62, P<0.0001$, Fig. $6 \mathrm{~b}$, Additional file 1: Table S3).

In contrast to grain Cd concentration, grain As concentration correlated significantly but negatively with the heading time. In 2014, the correlation coefficient was $-0.62(P<0.0001)$ at Youxian site, and $-0.20(P<0.0001)$ at Fuyang site (Fig. 7a, Additional file 1: Table S3). In 2015, there were also significant negative correlations between grain As concentrations with the heading time at all three sites (Fig. 7b, Additional file 1: Table S3).

Cadmium and As concentration in brown rice of different rice cultivars correlated significantly but negatively. In 2014, the correlation coefficient was $-0.49(P<0.0001)$ at Youxian and $-0.13(P=0.0043)$ at Fuyang (Additional file 2: Figure S2a, Additional file 1: Table S4). In 2015, significant negative correlations were obtained between grain $\mathrm{Cd}$ and $\mathrm{As}$ concentrations at all three sites (Additional file 2: Figure S2b, Additional file 1: Table S4).

\section{Prospective low Cd and low As Accumulating Rice Cultivars for South China}

Based on the results from the 5 trials at 3 sites across 2 years, a number of cultivars with stably low $\mathrm{Cd}$ or low As accumulation in grain were identified (Table 3). These cultivars accumulated $\mathrm{Cd}$ or As in brown rice at levels that were below the Chinese Food Safety Standards (GB 2762-2012) at all five trials, even at the Xiangtan site that had a relatively high total $\mathrm{Cd}$ concentration and a high $\mathrm{Cd}$ availability in the soil. Eight cultivars (ShenYou957, LongPing602, Weiyou402, WeiYou463, ZhuLiangYou168, T-You535, JieFengYoul and I-You 899) and 6 cultivars (YongYou17, YongYou538, Y-LiangYou1998, II-You310, GangYou94-11 and II-You936) were identified as low $\mathrm{Cd}$ or low As 

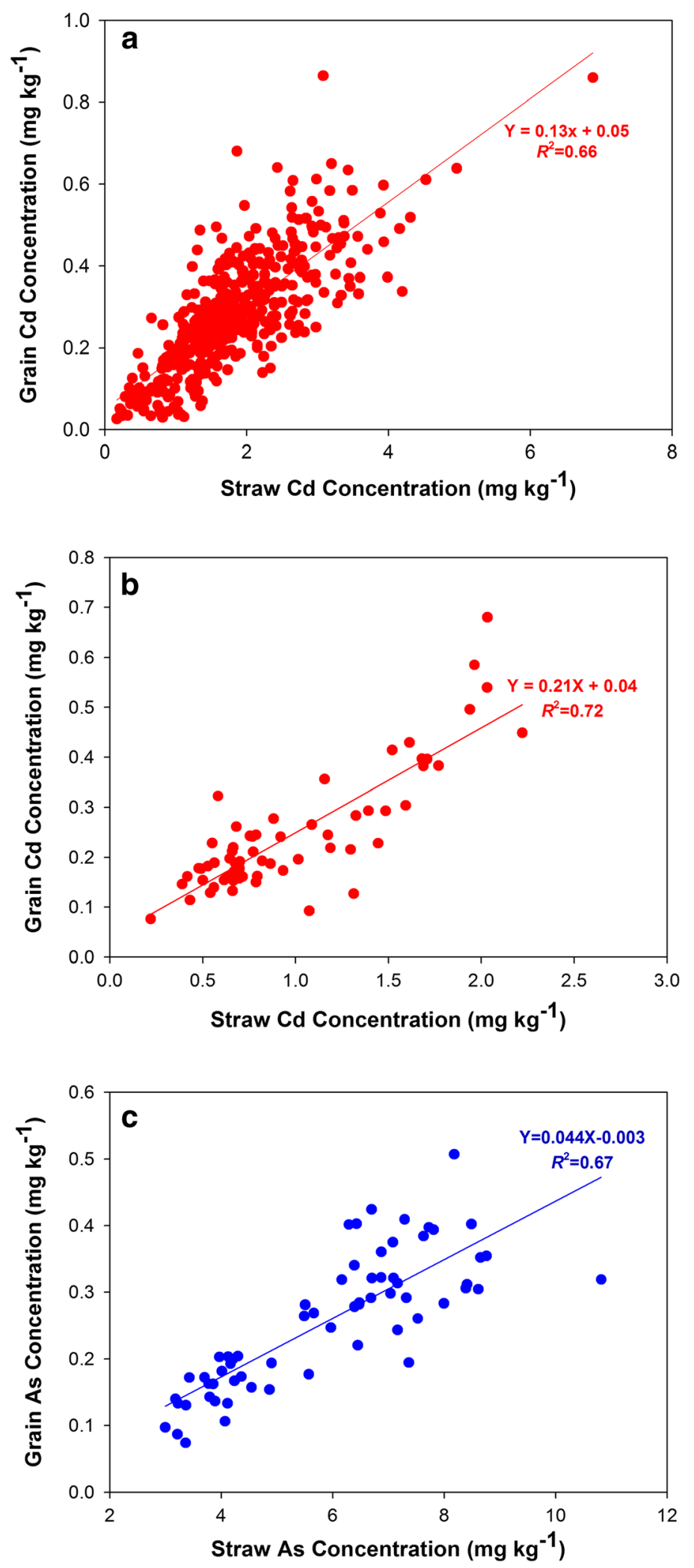

Fig. 5 Correlation between rice straw and grain Cd concentrations at Youxian in 2014 (a), Fuyang in 2015 (b) and between rice straw and grain As concentrations at Fuyang in 2015 (c) 

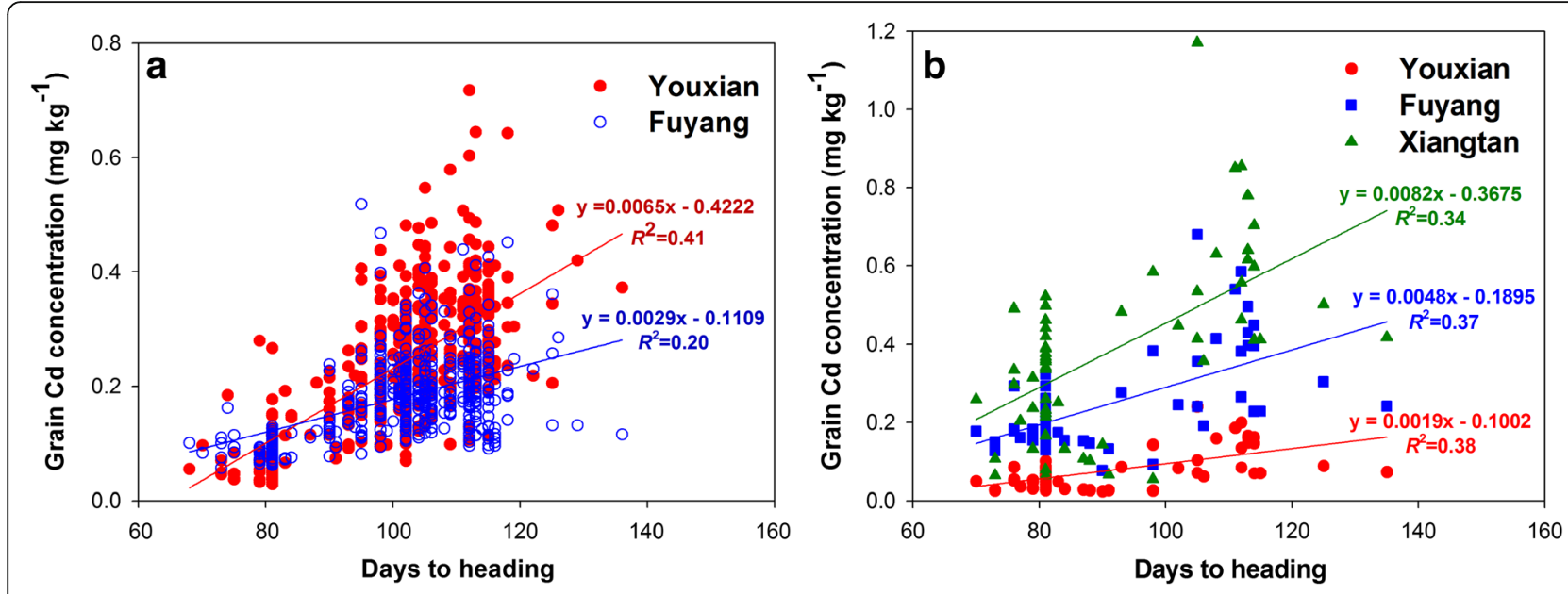

Fig. 6 Correlation between grain Cd concentration and heading time in 2014 (a) and 2015 (b)

cultivars, respectively. However, no cultivars could be considered to be low at both As and Cd. The low Cd cultivars had shorter heading time (80-90 days) than the low As cultivars $(110-130$ days).

\section{Discussion}

There have been a number of field studies on the genotypic variations of $\mathrm{As}$ and $\mathrm{Cd}$ concentrations in rice grain (Norton et al. 2009; 2012a; Kuramata et al., 2013; Pinson et al., 2015). However, most of these studies tested rice germplasm resources, and those accessions found to have low levels of As or $\mathrm{Cd}$ accumulation may not be suitable to the growth conditions in South China, where the problem of heavy metal and metalloid contamination is serious. In the present study, we screened a large number of rice cultivars that are high yielding and widely grown in South China. The results show a large genotypic variation in grain $\mathrm{Cd}$ concentration, exhibiting $10-32$ fold variation. In contrast, genotypic variation in grain As concentration was much smaller among the cultivars tested $(2.5-4$ fold $)$. A number of cultivars with stably low accumulation of either $\mathrm{Cd}$ or As in the grain were identified based on the trials conducted in multiple sites and seasons (Table 3). Grain $\mathrm{Cd}$ or As concentrations of these cultivars grown in paddy soils contaminated with moderate levels of $\mathrm{Cd}$ and $\mathrm{As}$ were below the maximum permissible limits of China (GB2762, 2012). Even at the Xiangtan site, which had a relatively high $\mathrm{Cd}$ level and a low soil pH (Table 1), these selected cultivars were still below the $\mathrm{Cd}$ limit. Therefore, these cultivars can be immediately usable in South China to control $\mathrm{Cd}$ and $\mathrm{As}$ in rice grain.

We found that grain $\mathrm{Cd}$ and As concentrations correlated significantly, but in opposite ways, with the heading time. Cultivars with early heading ( $<90$ days) tended to exhibit low $\mathrm{Cd}$ accumulation, whereas cultivars with late heading ( $>110$ days) tended to exhibit low As accumulation (Fig. 5 and 6). Similarly, Sun et al. (2016) found
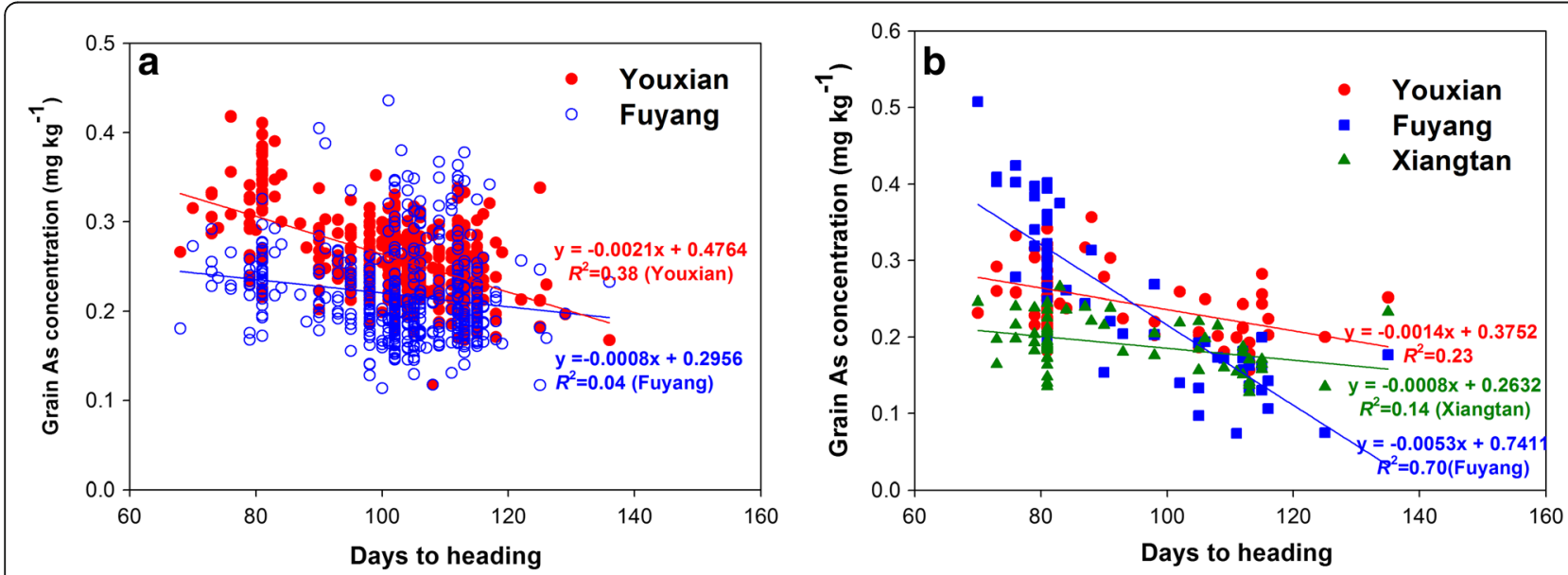

Fig. 7 Correlation between grain As concentration and heading time in 2014 (a) and 2015 (b) 
Table 3 Low Cd or low As accumulating rice cultivars selected based on multiple site and season trials

\begin{tabular}{|c|c|c|c|c|c|c|c|}
\hline \multirow[t]{2}{*}{ Low Cd cultivars } & \multirow[t]{2}{*}{ Heading days } & \multirow{2}{*}{$\begin{array}{l}2014 \text { Youxian } \\
\text { Grain Cd } \\
\left(\mathrm{mg} \mathrm{kg}^{-1}\right)\end{array}$} & \multicolumn{2}{|c|}{2015 Youxian } & \multirow{2}{*}{$\begin{array}{l}2014 \text { Fuyang } \\
\text { Grain Cd } \\
\left(\mathrm{mg} \mathrm{kg}^{-1}\right)\end{array}$} & \multirow{2}{*}{$\begin{array}{l}2015 \text { Fuyang } \\
\text { Grain Cd } \\
\left(\mathrm{mg} \mathrm{kg}^{-1}\right)\end{array}$} & \multirow{2}{*}{$\begin{array}{l}2015 \text { Xiangtan } \\
\begin{array}{l}\text { Grain Cd } \\
\left(\mathrm{mg} \mathrm{kg}^{-1}\right)\end{array}\end{array}$} \\
\hline & & & $\begin{array}{l}\text { Grain Cd } \\
\left(\mathrm{mg} \mathrm{kg}^{-1}\right)\end{array}$ & $\begin{array}{l}\text { Yield } \\
\left(\mathrm{kg} \mathrm{ha}^{-1}\right)\end{array}$ & & & \\
\hline ShenYou957 & 91 & 0.07 & 0.03 & 9275 & 0.09 & 0.09 & 0.06 \\
\hline LongPing602 & 98 & 0.09 & 0.03 & 9515 & 0.15 & 0.13 & 0.10 \\
\hline T-You535 & 84 & 0.15 & 0.03 & 8058 & 0.08 & 0.19 & 0.06 \\
\hline JieFengYou1 & 87 & 0.12 & 0.03 & 8147 & 0.11 & 0.19 & 0.11 \\
\hline I-You899 & 81 & 0.07 & 0.07 & 7226 & 0.06 & 0.15 & 0.17 \\
\hline WeiYou402 & 88 & n.g. & 0.03 & 8071 & n.g. & 0.15 & 0.06 \\
\hline WeiUou463 & 83 & n.g. & 0.05 & 8923 & n.g. & 0.15 & 0.06 \\
\hline ZhuLiangYou168 & 81 & 0.04 & 0.05 & 7935 & 0.06 & 0.16 & 0.13 \\
\hline Low As cultivars & Heading days & $\begin{array}{l}\text { Grain As } \\
\left(\mathrm{mg} \mathrm{kg}^{-1}\right)\end{array}$ & $\begin{array}{l}\text { Grain As } \\
\left(\mathrm{mg} \mathrm{kg}^{-1}\right)\end{array}$ & $\begin{array}{l}\text { Yield } \\
\left(\mathrm{kg} \mathrm{ha}^{-1}\right)\end{array}$ & $\begin{array}{l}\text { Grain As } \\
\left(\mathrm{mg} \mathrm{kg}^{-1}\right)\end{array}$ & $\begin{array}{l}\text { Grain As } \\
\left(\mathrm{mg} \mathrm{kg}^{-1}\right)\end{array}$ & $\begin{array}{l}\text { Grain } \\
\left(\mathrm{mg} \mathrm{kg}^{-1}\right)\end{array}$ \\
\hline YongYou17 & 125 & 0.18 & 0.2 & 7192 & 0.12 & 0.07 & 0.13 \\
\hline YongYou538 & 123 & 0.19 & 0.19 & 8675 & 0.16 & 0.14 & 0.14 \\
\hline GangYou94-11 & 113 & 0.18 & 0.18 & 9565 & 0.16 & 0.17 & 0.14 \\
\hline Y-LiangYou1998 & 112 & 0.17 & 0.16 & 8741 & 0.16 & 0.16 & 0.13 \\
\hline II-You936 & 115 & 0.18 & 0.19 & 9549 & 0.15 & 0.10 & 0.18 \\
\hline 1I-You310 & 113 & 0.20 & 0.17 & 10072 & 0.17 & 0.13 & 0.17 \\
\hline
\end{tabular}

n.g. not grown

that early flowering cultivars accumulated significantly lower $\mathrm{Cd}$ in the grain than later flowering cultivars. Norton et al. (2012b) reported a negative correlation between grain As concentration and flowering time in a recombinant inbred line (RIL) population derived from a cross between Bala, an Indica variety, and Azucena, a Japonica variety. Norton et al. (2012a) also found a colocalization of QTLs for flowering time and grain As concentration on chromosomes 8 and 10. When grain As data were adjusted against the heading date data, the two grain As QTLs were no longer detected, suggesting that the two traits are linked. However, whether this linkage is underpinned by physiology remains unclear. It is possible that both grain As and Cd concentrations are influenced indirectly by heading time via soil chemistry, which strongly depends on the paddy water management. It is well known that flooding of paddy soil reduces Cd bioavailability but increases As bioavailability (Xu et al. 2008; Li et al. 2009; Arao et al. 2009; Zhao et al. 2015). Draining paddy water during the later phase of grain filling is a normal agronomic practice for rice cultivation. Therefore, cultivars with early heading time might have experienced flooded conditions during most of the grain filling period, resulting in low $\mathrm{Cd}$ and high As bioavailability in the soil, and hence low $\mathrm{Cd}$ and high As accumulation in the grain. In contrast, cultivars with late heading might have encountered drained soil conditions during the grain filling period, leading to high $\mathrm{Cd}$ and low As bioavailability in the soil, and hence high $\mathrm{Cd}$ and low As accumulation in the grain. The opposite effect of water management on As and Cd availability in soil may also explain the negative correlation between As and $\mathrm{Cd}$ concentrations in rice grain (Additional file 2: Figure S2, Additional file 1: Table S4). In 2015, cultivars were separated into early, middle and late heading groups and planted into 3 subplots within each replicate at two sites (Youxian and Xiangtan) to allow paddy water management to be tailored according to heading time. The positive and negative relationships between heading date and grain $\mathrm{Cd}$ and As, respectively, were still apparent in these two trials (Figs. 6 and 7), suggesting possible physiological mechanisms underlying these relationships. The negative correlation between grain $\mathrm{Cd}$ and As concentrations suggests that it would be difficult to find cultivars with low accumulation of both $\mathrm{Cd}$ and As. One way to circumvent this dilemma has recently been tested by Ishikawa et al. (2016), who grew a rice mutant with nonfunctional OsNramp5 under aerobic soil conditions and achieved low accumulation of both $\mathrm{Cd}$ and As in grain.

In addition to environmental factors, rice genotype is a key factor controlling $\mathrm{As}$ and $\mathrm{Cd}$ accumulation in rice grain (Norton et al., 2009; Pinson et al., 2015). A number of QTLs have been reported to be associated with rice grain As accumulation (Zhang et al., 2008; Norton et al., 2012a; Kuramata et al., 2013; Pinson et al., 2015) or Cd accumulation (Ishikawa et al. 2005; Ueno et al., 2009; Zhang et al., 2011; Abe et al., 2013). However, so far only a QTL for shoot and grain Cd concentration located on the chromosome 7 has been cloned, with OsHMA3 as 
the causal gene explaining the genotypic variation (Ueno et al. 2010; Miyadate et al. 2011). This gene encodes a $\mathrm{Cd}$ transporter localized on the tonoplast functioning to sequester $\mathrm{Cd}$ in the vacuoles of root cells, thus limiting $\mathrm{Cd}$ translocation to the shoots and grain (Ueno et al. 2010; Miyadate et al. 2011). Several loss-of-function alleles of OsHMA3 have been identified in a number of Indica (Ueno et al. 2010; Miyadate et al. 2011) and Japonica (Yan et al., 2016) cultivars, leading to high accumulation of $\mathrm{Cd}$ in rice grain. However, these loss-offunction alleles are rare among collections of rice cultivars and germplasm (Yan et al. 2016). It is possible that other functional alleles of OsHMA3 may vary in the functionality by exhibiting different transport activities for $\mathrm{Cd}$. This possibility remains to be tested. The strong linear relationship between straw and brown rice $\mathrm{Cd}$ or As concentrations (Fig. 5) is consistent with the suggestion that the root to shoot translocation of $\mathrm{Cd}$ and $\mathrm{As}$ is the key process controlling the accumulation of $\mathrm{Cd}$ or As in rice grain (Uraguchi et al. 2009; Zhao et al., 2009). However, there was also substantial variation in the ratio of brown rice $\mathrm{Cd}$ or As to straw $\mathrm{Cd}$ or As concentrations, suggesting genotypic variation in the translocation from leaves and stems to rice grain. In addition, the ratio of brown rice $\mathrm{Cd}$ to straw $\mathrm{Cd}$ concentration was much higher than that of As, indicating that $\mathrm{Cd}$ is more mobile during translocation from straw to grain.

A number of other genes are known to be involved in $\mathrm{Cd}$ or As uptake and translocation in rice, but it remains unknown if there are allelic variations of these genes that can explain the variations in grain $\mathrm{Cd}$ or $\mathrm{As}$ accumulation. Examples include OsNramp5 responsible for the uptake of $\mathrm{Cd}$ into the root cells (Ishikawa et al., 2012; Sasaki et al. 2012; Yang et al. 2014), OsHMA2 and OsLCT1 for Cd re-distribution between rice tissues (Uraguchi et al. 2011; Satoh-Nagasawa et al. 2012), OsLsi1 and OsLsi2 for arsenite uptake into rice roots (Ma et al. 2008), OsABCC1 for arsenite sequestration into the vacuoles (Song et al., 2010), OsHAC1;1 and OsHAC1;2 for arsenate reduction to allow subsequent arsenite efflux (Shi et al. 2016), and plant inositol transporters for arsenite loading to the phloem and regulating As accumulation in the seeds of Arabidopsis thaliana (Duan et al., 2016). Identification of alleles that can limit $\mathrm{Cd}$ or As accumulation in the grain is prerequisite for breeding low accumulation cultivars using marker assisted selection approach.

It has been reported that Indica rice cultivars tend to accumulate higher levels of $\mathrm{Cd}$ in shoots and grain than Japonica cultivars (Liu et al. 2005; He et al. 2006; Uraguchi \& Fujiwara 2013; Sun et al. 2016). However, no significant difference between Indica and Japonica cultivars for either As or $\mathrm{Cd}$ concentration in the grain was found in the present study (Additional file 2: Figure S3). There are large genotypic variations among both Japonica and Indica cultivars (Ueno et al., 2009). Pinson et al. (2015) and Yan et al. (2016) showed that some Japonica cultivars can accumulate high $\mathrm{Cd}$ concentrations. Therefore, depending on the cultivars tested, Japonica cultivars as a group may not always show a significant lower $\mathrm{Cd}$ accumulation than the Indica group. It has also been claimed that hybrid rice can accumulate more $\mathrm{Cd}$ and As than non-hybrids (Gong et al., 2006; Rahman et al. 2007). However, in this study, there was no significant difference between hybrid and non-hybrid cultivars in As or Cd concentrations in brown rice (Additional file 2: Figure S3). A recent study by Sun et al. (2016) also showed no significant difference in grain $\mathrm{Cd}$ concentration between Indica hybrids and Indica inbred cultivars. It is the genetic diversity rather than the type of hybrid versus inbred that determines the relative Cd accumulation among rice cultivars (Sun et al. 2016).

\section{Conclusions}

For both grain $\mathrm{Cd}$ and As concentrations, there were significant $G \times$ E interactions in the present study. Despite these interactions, the results show that it is possible to identify locally adapted rice cultivars with low accumulation of $\mathrm{Cd}$ or As in the grain with the trait being stable across multiple sites and seasons. These cultivars (or their hybrid parents) can be valuable materials for investigating the genetics underpinning low accumulation of As and Cd. However, it is difficult to select cultivars with low accumulation of both $\mathrm{Cd}$ and As.

\section{Methods}

\section{Rice Cultivars}

In 2014, 471 rice cultivars (Additional file 1: Table S1) were grown at two field sites contaminated with moderate levels of $\mathrm{Cd}$. These cultivars are commonly grown in large acreage in southern China, with approximately 300 cultivars being the main cultivars in Hunan province, where $\mathrm{Cd}$ and As contamination in paddy soils are widespread. The majority (425) of the cultivars are Indica rice, among which 408 and 17 are hybrid and conventional cultivars, respectively. The remainders (46) are conventional Japonica cultivars. The days to heading of these cultivars varied from 68 to 136 days (from germination to full heading).

Base on the results of the trials in 2014, 52 rice cultivars were selected for further trials at three sites in 2015 . These included 44 cultivars with low grain $\mathrm{Cd}$ concentrations, 3 cultivars with high $\mathrm{Cd}$ concentrations, and 5 cultivars with low As concentrations. Because most of the 52 selected cultivars are relatively early heading, 11 additional main rice cultivars with late heading were also included in the trials in 2015, giving rise to a total number of 63 rice cultivars (Additional file 1: Table S1). 


\section{Field Sites}

The field experimental sites in 2014 were located in Youxian county, Hunan province (latitude $27^{\circ} 08^{\prime}$; longitude $113^{\circ} 22^{\prime}$ ) and in the Fuyang district of Hangzhou city, Zhejiang province (latitude $30^{\circ} 07^{\prime}$; longitude $119^{\circ}$ 95'). The total $\mathrm{Cd}$ concentrations in the paddy soils were around 0.5 and $0.4 \mathrm{mg} \mathrm{kg}^{-1}$ for Youxian and Fuyang sites, respectively (Table 1 ), both exceeding the $\mathrm{Cd}$ limit of the Chinese soil environmental quality standard (0.3 $\mathrm{mg} \mathrm{kg}^{-1}$ for soils with $\left.\mathrm{pH}<7.5\right)(\mathrm{GB} 15618,1995)$. The total soil As concentrations were about 20 and $12 \mathrm{mg} \mathrm{kg}^{-1}$ for Youxian and Fuyang sites, respectively (Table 1), both were higher than the background level of As $\left(<10 \mathrm{mg} \mathrm{kg}^{-1}\right)$, but still below the As limit of the Chinese soil environmental quality standard $\left(30 \mathrm{mg} \mathrm{kg}^{-1}\right.$ for paddy soils) (GB 15618, 1995). The soils at the Youxian Fuyang site are acidic ( $\mathrm{pH} 4.9$ - 5.6). In 2015, field experiments were conducted at three sites, including the two sites used in 2014, and an additional site at Xiangtan city, Hunan province (latitude $27^{\circ} 83^{\prime}$; longitude $112^{\circ} 91^{\prime}$ ). At Xiangtan site, the soil is also acidic ( $\mathrm{pH} 4.9)$ and contains a higher level of $\mathrm{Cd}\left(1.4 \mathrm{mg} \mathrm{kg}^{-1}\right)$ than the other sites, but a similar level of total As $\left(19 \mathrm{mg} \mathrm{kg}^{-1}\right)$.

\section{Rice Cultivation}

Single-cropping rice cultivation was conducted in both 2014 and 2015. Seeds were germinated and sown on seedbeds in early May, and transplanted to the field plots in early June. Seedlings of different cultivars were transplanted in randomized block design with 3 replicates. In each replicate, each genotype was planted in 3 (in 2014) or 20 rows (in 2015) of 10 hills (1 seedling per hill). The distance between row and hills was $20 \mathrm{~cm}$. To separate different cultivars, $40 \mathrm{~cm}$ unplanted area was included between adjacent cultivars. Paddy field water was managed according to the local practices, with paddy fields being flooded during the rice growth season except the late tillering stage and one week before harvesting when water was drained. In 2015 at Youxian and Xiangtan sites, cultivars were grouped into early, middle and late heading groups, which were planted into 3 subplots within each replicate to allow water management of each subplot depending on the heading time. Compound fertilizers $\left(16 \% \mathrm{~N}, 16 \% \mathrm{P}_{2} \mathrm{O}_{5}, 16 \% \mathrm{~K}_{2} \mathrm{O}\right)$ were applied at three times, 200, 100 and $100 \mathrm{~kg} / \mathrm{ha}$, respectively, at one day before transplanting and 10 and 30 days after transplanting. In the two latter applications, $60 \mathrm{~kg} / \mathrm{ha}$ of urea was also applied. Fungicides and pesticides were applied according to the local practices for rice crops. Plants of each cultivar were harvested 30 days after full heading, between August and October. Grain and straw from the central 6 hills were harvested and pooled together for elemental analysis. Plants were cut from about $20 \mathrm{~cm}$ above the soil surface and placed in a nylon mesh bag.
Samples were dried under the sunlight and then separated into grain and straw.

Grain yield of each cultivar was estimated at Youxian in 2015. Approximately 100 hills were harvested from each replicate plot of each cultivar. Grain were dried and weighed. Grain yield was calculated by using the planting density of 250000 hills per hectare.

\section{Plant and Soil Analysis}

Soil samples were taken before transplanting. From each field, three composite soil samples were collected from the three blocks of the experiment, each consisting of five cores randomly taken from the 0-20 cm depth within the block. Soil samples were air-dried and crushed to pass through a 2-mm nylon sieve. A portion of each soil sample was ground with an agate grinder to pass through a $0.15 \mathrm{~mm}$ nylon sieve. For the determination of the concentrations of $\mathrm{Cd}$, As and other heavy metals, 0.2 g finely ground soil sample was weighed into a quartz glass tube, to which $2.5 \mathrm{ml}$ of high purity nitric acid was added and left to stand overnight. Hydrogen peroxide $(2.5 \mathrm{ml}, 30 \%)$ was then added and the sample was digested on a block digester at $100{ }^{\circ} \mathrm{C}$ for $1 \mathrm{~h}, 120{ }^{\circ} \mathrm{C}$ for $1 \mathrm{~h}$, and $140{ }^{\circ} \mathrm{C}$ for $4 \mathrm{~h}$. The concentrations of $\mathrm{Cd}$ and As in the digest solution were determined by inductively coupled plasma mass spectrometry (ICP-MS; Perkin-Elmer Nexion 300x). For quality control, a certified reference soil (GBW 07405, China Standard Materials Research Center, Beijing, China) was included in the analysis. The average recovery of for Cd and As ranged from 91 to $105 \%$ and from 97 to $103 \%$, respectively. Soil $\mathrm{pH}$ was determined using a combined glass electrode in a suspension of soil $(<2 \mathrm{~mm})$ and deionized water $(1: 2.5, \mathrm{w} / \mathrm{v})$.

Grain samples were separated into husks and brown (unpolished) rice using a de-husking machine (JLGJ45, Taizhou Food Instrument Factory, Taizhou, China). Brown rice and straw samples were oven-dried at $65{ }^{\circ} \mathrm{C}$ for 3 days, and ground to fine powders using a mill (JNMJ3, Taizhou Food Instrument Factory, Taizhou, China). Plant samples ( $0.2 \mathrm{~g}$ of rice grain and $0.1 \mathrm{~g}$ of straw) were digested with $2 \mathrm{ml}$ of high purity nitric acid in a microwave digestion oven (Mars 5, CEM Corporation, USA) using the following program, $55{ }^{\circ} \mathrm{C}$ for $10 \mathrm{~min}, 75{ }^{\circ} \mathrm{C}$ for $10 \mathrm{~min}$, and $95{ }^{\circ} \mathrm{C}$ for $30 \mathrm{~min}$. After cooling, the remaining acid was evaporated and the digests were dissolved in $30 \mathrm{~mL} 2 \% \mathrm{HNO}_{3}$. The concentrations of $\mathrm{Cd}$ and $\mathrm{As}$ in the digest solutions were determined by ICP-MS (Perkin-Elmer Nexion 300x). For quality control, a certified reference material (rice flour GBW-10010, China Standard Materials Research Center, Beijing, China) was included in the analysis. The average recovery for $\mathrm{Cd}$ and As ranged from 89 to $102 \%$ and from 92 to $105 \%$, respectively. 


\section{Statistical Analysis}

All data were subjected to two-way analysis of variance (ANOVA) followed by Student-Newman-Keuls multiple comparisons using windows-based SPSS 11.5. Data presented are means $\pm \mathrm{SD}(n=3)$. Curve fitting was performed using SigmaPlot 10.0.

\section{Additional Files}

Additional file 1: List of rice cultivars used for this study. (XLSX $22 \mathrm{~kb}$ )

Additional file 2: Boxplots of grain $\mathrm{Cd}$ and As concentrations of different rice subgroups, and correlation of grain As and Cd concentrations and with grain yield respectively. (DOCX $251 \mathrm{~kb}$ )

\section{Acknowledgments}

The study was funded by the special fund for agro-scientific research in the public interest (grant no. 201403015) and the Natural Science Foundation of China (grant no. 41371458 and 31520103914 ).

\section{Authors' Contributions}

Guilan Duan performed screening in Youxian, Guosheng Shao performed screening in Fuyang, Zhong Tang performed screening in Xiangtan. Hongping Chen, Boxun Wang, Zhu Tang, Yuping Yang, Yuechuan Liu performed plant growing and sample analysis. Fang-Jie Zhao designed the research. Guilan Duan and Fang-Jie Zhao analyzed the data and wrote the manuscript. All authors read and approved the final manuscript.

\section{Competing Interests}

The authors declare no competing financial interests.

\section{Publisher's Note}

Springer Nature remains neutral with regard to jurisdictional claims in published maps and institutional affiliations.

\section{Author details \\ ${ }^{1}$ State Key Laboratory of Urban and Regional Ecology, Research Centre for Eco-Environmental Sciences, Chinese Academy of Sciences, Beijing 100085 China. ${ }^{2}$ Chinese National Rice Research Institute, Hangzhou 310006, China. ${ }^{3}$ State Key Laboratory of Crop Genetics and Germplasm Enhancement, College of Resources and Environmental Sciences, Nanjing Agricultural University, Nanjing 210095, China. ${ }^{4}$ Youxian Agricultural Bureau of Hunan Province, Hunan 412300, China.}

Received: 16 December 2016 Accepted: 17 March 2017

Published online: 28 March 2017

\section{References}

Abe T, Nonoue Y, Ono N, Omoteno M, Kuramata M, Fukuoka S, Yamamoto T, Yano M, Ishikawa S (2013) Detection of QTLs to Reduce Cadmium Content in Rice Grains Using LAC23/Koshihikari Chromosome Segment Substitution Lines. Breed Sci 63(3):284-291

Arao T, Kawasaki A, Baba K, Mori S, Matsumoto S (2009) Effects of Water Management on Cadmium and Arsenic Accumulation and Dimethylarsinic Acid Concentrations in Japanese Rice. Environ Sci Technol 43(24):9361-9367

Bhattacharyya MH, Sacco-Gibson NA, Peterson DP (1992) Cadmium-Induced Bone Loss: Increased Susceptibility in Female Beagles After Ovariectomy. IARC Sci Publ 118:279-286

Bolan NS, Adriano CC, Duraisamy P, Mani A, Arulmozhiselvan K (2003) Immobilization and Phytoavailability of Cadmium in Variable Charge Soils. 1. Effect of Phosphate Addition. Plant Soil 250:83-94

Chaney RL, Kim WI, Kunhikrishnan A, Yang JE, Yong SO (2016) Integrated Management Strategies for Arsenic and Cadmium in Rice Paddy Environments. Geoderma 270:1-2

Chen CJ, Chuang YC, You SL, Lin TM, Wu HY (1986) A Retrospective Study on Malignant Neoplasms of Bladder, Lung and Liver in Blackfoot Disease Endemic Area in Taiwan. Br J Cancer 53(3):399-405
Clemens S, Ma JF (2016) Toxic Heavy Metal and Metalloid Accumulation in Crop Plants and Foods. Ann Rev Plant Biol 67:489-512

Deng L, Li Z, Wang J, Liu H, Li N, Wu L, Hu P, Luo Y, Christie P (2015) Long-Term Field Phytoextraction of Zinc/Cadmium Contaminated Soil by Sedum Plumbizincicola Under Different Agronomic Strategies. Inter J Phytorem 18(2):134-140

Dittmar J, Voegelin A, Roberts LC, Hug SJ, Saha GC, Ali MA, Badruzzaman ABM, Kretzschmar R (2010) Arsenic Accumulation in a Paddy Field in Bangladesh: Seasonal Dynamics and Trends Over a Three-Year Monitoring Period. Environ Sci Technol 44(8):2925-2931

Du Y, Hu XF, Wu XH, ShuY JY, Yan XJ (2013) Affects of Mining Activities on Cd Pollution to the Paddy Soils and Rice Grain in Hunan Province, Central South China. Environ Monit Assess 185(12):9843-9856

Duan GL, Hu Y, Schneider S, McDermott J, Chen J, Sauer N, Rosen BP, Daus B, Liu Z, Zhu YG (2016) Inositol Transporters AtINT2 and AtINT4 Regulate Arsenic Accumulation in Arabidopsis Seeds. Nat Plants 2(1):15202.

Duan GL, Zhang HM, Liu YX, Jia Y, Hu Y, Cheng WD (2012) Long-Term Fertilization With pig-Biogas Residues Results in Heavy Metal Accumulation in Paddy Field and Rice Grains in Jiaxing of China. Soil Sci Plant Nutr 58:637646

GB 15618, (1995) National Environmental Protection Bureau Environmental quality standard for soils GB 15618-1995.

GB 2715 (2005) Chinese Food Hygiene Standards. Standards Press of China, Beijing

GB2762 (2012) Chinese Food Hygiene Standards. Standards Press of China, Beijing

Gong WQ, Li LQ, Pan GX (2006) Cd Uptake and Accumulation in Grains by Hybrid Rice in two Paddy Soils: Interactive Effect of Soil Type and Cultivars. Environ Sci 27:1647-1653

He JY, Zhu C, Ren YF, Yan Y, Jiang D (2006) Genotypic Variation in Grain Cadmium Concentration of Lowland Rice. J Plant Nutr Soil Sci 169:711-716

Hu P, Huang J, Ouyang Y, Zhou LQ, Huang JX, Huang YJ, Luo YM, Christie P, Wu LH (2013) Water Management Affects Arsenic and Cadmium Accumulation in Different Rice Cultivars. Environ Geochem Health 35(6):767-78

IARC (1993) IARC Monographs on the evaluation of carcinogenic risks to humans, Vol.58 Beryllium, Cadmium, Mercury, and Exposures in the Glass Manufacturing Industry, Lyon. http://www.iarc.fr

Ishikawa S, Makino T, Ito M, Harada K, Nakada H, \& Nishida I, Nishimura M, Tokunaga T, Shirao K, Yoshizawa C, Matsuyama M, Abe T, Arao T (2016). Lowcadmium rice (oryza sativa I.) cultivar can simultaneously reduce arsenic and cadmium concentrations in rice grains. Soil Science and Plant Nutrition. 62(4); $1-13$.

Ishikawa S, Ishimaru Y, Igura M, Kuramata M, Abe T, Senoura T, Hase Y, Arao T, Nishizawa NK, Nakanishi H (2012) Ion-Beam Irradiation, Gene Identification, and Marker-Assisted Breeding in the Development of low-Cadmium Rice. Proc Natl Acad Sci U S A 109(47):19166-19171

Ishikawa S, Ae N, Yano M (2005) Chromosomal Regions With Quantitative Trait Loci Controlling Cadmium Concentration in Brown Rice (Oryza Sativa). New Phytol 168(2):345-350

Kuramata M, Abe T, Kawasaki A, Ebana K, Shibaya T, Yano M, Ishikawa S (2013) Genetic Diversity of Arsenic Accumulation in Rice and QTL Analysis of Methylated Arsenic in Rice Grains. Rice 6(1):3

Li G, Sun GX, Williams PN, Nunes L, Zhu YG (2011) Inorganic Arsenic in Chinese Food and its Cancer Risk. Environ Int 37:1219-1225

Li RY, Stroud JL, Ma JF, McGrath SP, Zhao FJ (2009) Mitigation of Arsenic Accumulation in Rice With Water Management and Silicon Fertilization. Environ Sci Technol 43:3778-3783

Liu JG, Zhu QS, Zhang ZJ, Xu JK, Yang JC, Wong MH (2005) Variations in Cadmium Accumulation Among Rice Cultivars and Types and the Selection of Cultivars for Reducing Cadmium in the Diet. J Sci Food Agric 85(1):147-153

Ma JF, Yamaji N, Mitani N, Xu XY, Su YH, McGrath SP, Zhao FJ (2008) Transporters of Arsenite in Rice and Their Role in Arsenic Accumulation in Rice Grain. Proc Natl Acad Sci U S A 105:9931-9935

Mandal A, Purakayastha TJ, Patra AK, Sanyal SK (2012) Phytoremediation of Arsenic Contaminated Soil by Pteris Vittata ii. Effect on Arsenic Uptake and Rice Yield. Inter J Phytorem 14(6):621-628

MEP, (2014) The Ministry of Environmental Protection; The Ministry of Land and Resources Report on the national soil contamination survey. http://www. mep.gov.cn/gkml/hbb/qt/201404/t20140417_270670.htm.

Miyadate H, Adachi S, Hiraizumi A, Tezuka K, Nakazawa N, Kawamoto T, Katou K, Kodama I, Sakurai K, Takahashi H, Satoh-Nagasawa N, Watanabe A, Fujimura 
T, Akagi H (2011) OsHMA3, a P1B-Type of ATPase Affects Root-to-Shoot Cadmium Translocation in Rice by Mediating Efflux into Vacuoles. New Phytol 189(1):190-199

Mondal D, Polya DA (2008) Rice is a Major Exposure Route for Arsenic in Chakdaha Block, Nadia District, West Bengal, India: A Probabilistic Risk Assessment. Appl Geochem 23(11):2987-2998

Murakami M, Nakagawa F, Ae N, Ito M, Arao T (2009) Phytoextraction by Rice Capable of Accumulating Cd at High Levels: Reduction of Cd Content of Rice Grain. Environ Sci Technol 43:5878-5883

Murata I, Hirano T, Saeki Y, Nakagawa S (1970) Cadmium Enteropathy, Renal Osteomalacia ("Ita-Ita"Disease in Japan). Bull Soc Int Chir 29:34-42

Nordstrom DK (2002) Public Health-Worldwide Occurrences of Arsenic in Ground Water. Science 296:2143-2145

Norton GJ, Duan GL, Lei M, Zhu YG, Meharg AA, Price AH (2012a) Identification of Quantitative Trait Loci for Rice Grain Element Composition on an Arsenic Impacted Soil: Influence of Flowering Time on Genetic Loci. Ann Appl Biol 161:46-56

Norton GJ, Pinson SRM, Alexander J, McKay S, Hansen H, Duan GL, Islam MR, Islam S, Stroud JL, Zhao FJ, McGrath SP, Zhu YG, Lahner B, Yakubova E, Guerinot ML, Tarpley L, Eizenga GC, Salt DE, Meharg AA, Price AH (2012b) Variation in Grain Arsenic Assessed in a Diverse Panel of Rice (Oryza Sativa) Grown in Multiple Sites. New Phytol 193:650-664

Norton GJ, Duan GL, Dasgupta T, Islam MR, Lei M, Zhu YG, Deacon CM, Moran AC, Islam S, Zhao FJ, Stroud JL, McGrath SP, Feldmann J, Price AH, Meharg AA (2009) Environmental and Genetic Control of Arsenic Accumulation and Speciation in Rice Grain: Comparing a Range of Common Cultivars Grown in Contaminated Sites Across Bangladesh, China and India. Environ Sci Technol 43:8381-8386

NTP (2000) National Toxicology Program, Tenth Report on Carcinogens. Department of Health and Human Services, Research Triangle Park, pp III-42III-44

Pinson SRM, Tarpley L, Yan WG, Yeater K, Lahner B, Yakubova E, Huang XY, Zhang M, Guerinot ML, Salt DE (2015) Worldwide Genetic Diversity for Mineral Element Concentrations in Rice Grain. Crop Sci 55(1):294-311

Rahman MA, Hasegawa H, Rahman MM, Islam MN, Miah MAM, Tasmin A (2007) Arsenic Accumulation in Rice (Oryza Sativa L.) Varieties of Bangladesh: A Glass House Study. Water Air Soil Pollut 185:53-61

Sasaki A, Yamaji N, Yokosho K, Ma JF (2012) Nramp5 is a Major Transporter Responsible for Manganese and Cadmium Uptake in Rice. Plant Cell 24(5):2155-2167

Satarug S, Moore M (2004) Adverse Health Effect of Chronic Exposure to lowLevel Cadmium in Food Stuffs and Cigarette Smoke. Environ Health Perspect 112:1099-1103

Satoh-Nagasawa N, Mori M, Nakazawa N, Kawamoto T, Nagato Y, Sakurai K, Takahashi H, Watanabe A, Akagi H (2012) Mutations in Rice (Oryza Sativa) Heavy Metal ATPase 2 (OsHMA2) Restrict the Translocation of Zinc and Cadmium. Plant Cell Physiol 53(1):213-224

Shi SL, Wang T, Chen Z, Tang Z, Wu ZC, Salt DE, Chao DY, Zhao FJ (2016) OsHAC1;1 and OsHAC1;2 Function as Arsenate Reductases and Regulate Arsenic Accumulation. Plant Physiol 172:1708-1719

Signes-Pastor AJ, Carey M, Meharg AA (2016) Inorganic Arsenic in Rice-Based Products for Infants and Young Children. Food Chem 191:128-134

Smith A, Lingas E, Rahman M (2000) Contamination of Drinking-Water by Arsenic in Bangladesh: A Public Health Emergency. Bull WHO 78:1093-1103

Song WY, Park J, Mendoza-Cózatl DG, Suter-Grotemeyer M, Shim D, Hörtensteiner S, Geisler M, Weder B, Rea PA, Rentsch D, Schroeder JI, Lee Y, Martinoia E (2010) Arsenic Tolerance in Arabidopsis is Mediated by two ABCC-Type Phytochelatin Transporters. Proc Natl Acad Sci U S A 107(49):21187-21192

Sun L, Xu XX, Jiang YR, Zhu QH, Yang F, Zhou JQ, Yang YZ, Huang ZY, Li AH, Chen LH, Tang WB, Zhang GY, Wang JR, Xiao GY, Huang DY, Chen CY (2016) Genetic Diversity, Rather Than Cultivar Type, Determines Relative Grain cd Accumulation in Hybrid Rice. Front Plant Sci 7:1407

Tsukahara T, Ezaki T, Moriguchi J, Furuki K, Shimbo S, Matsuda-Inoguchi N, Ikeda M (2003) Rice as the Most Influential Source of Cadmium Intake Among General Japanese Population. Sci Total Environ 305:41-51

Ueno D, Kono I, Yokosho K, Ando T, Yano M, Ma JF (2009) A Major Quantitative Trait Locus Controlling Cadmium Translocation in Rice (Oryza Sativa). New Phytol 182(3):644-653

Ueno D, Yamaji N, Kono I, Huang CF, Ando T, Yano M, Ma JF (2010) Gene Limiting Cadmium Accumulation in Rice. Proc Natl Acad Sci U S A 107: 16500-16505
Uraguchi S, Fujiwara T (2013) Rice Breaks Ground for Cadmium-Free Cereals. Curr Opin Plant Biol 16(3):328-334

Uraguchi S, Kamiya T, Sakamoto T, Kasai K, Sato Y, Nagamura Y, Yoshida A, Kyozuka J, Ishikawa S, Fujiwara T (2011) Low-Affinity Cation Transporter (OsLCT1) Regulates Cadmium Transport into Rice Grains. Proc Natl Acad Sci U S A 108:20959-20964

Uraguchi S, Mori S, Kuramata M, Kawasaki A, Arao T, Ishikawa S (2009) Root-toShoot Cd Translocation via the Xylem is the Major Process Determining Shoot and Grain Cadmium Accumulation in Rice. J Exp Bot 60:2677-2688

Williams PN, Raab A, Feldmann J, Meharg AA (2007) Market Basket Survey Shows Elevated Levels of As in South Central US Processed Rice Compared to California: Consequences for Human Dietary Exposure. Environ Sci Technol 41:2178-2183

Williams PN, Lei M, Sun G, Huang Q, Lu Y, Deacon C, Meharg AA, Zhu YG (2009) Occurrence and Partitioning of Cadmium, Arsenic and Lead in Mine Impacted Paddy Rice: Hunan, China. Environ Sci Technol 43:637-642

Xu XY, McGrath SP, Meharg AA, Zhao FJ (2008) Growing Rice Aerobically Markedly Decreases Arsenic Accumulation. Environ Sci Technol 42:5574-5579

Yan J, Wang P, Wang P, Yang M, Lian X, Tang Z, Huang CF, Salt DE, Zhao FJ (2016) A Loss-of-Function Allele of OsHMA3 Associated With High Cadmium Accumulation in Shoots and Grain of Japonica Rice Cultivars. Plant Cell Environ 39(9):1941-1954

Yang M, Zhang Y, Zhang L, Hu J, Zhang X, Lu K, Dong H, Wang D, Zhao FJ, Huang CF, Lian XM (2014) OsNRAMP5 Contributes to Manganese Translocation and Distribution in Rice Shoots. J Exp Bot 65(17):4849-4861

Zhang J, Zhu YG, Zeng DL, Cheng WD, Qian Q, Duan GL (2008) Mapping Quantitative Trait Loci Associated With Arsenic Accumulation in Rice (Oryza Sativa L.). New Phytol 177:350-355

Zhang XQ, Zhang GP, Guo LB, Wang HZ, Zeng DL, Dong GJ, Qian Q, Xue DW (2011) Identification of Quantitative Trait Loci for Cd and Zn Concentrations of Brown Rice Grown in Cd-Polluted Soils. Euphytica 180(2):173-179

Zhao FJ, Ma JF, Meharg AA, McGrath SP (2009) Arsenic Uptake and Metabolism in Plants. New Phytol 181:777-794

Zhao FJ, Ma Y, Zhu YG, Tang Z, McGrath SP (2015) Soil Contamination in China: Current Status and Mitigation Strategies. Environ Sci Technol 49(2):750-759

Zhao FJ, McGrath SP, Meharg AA (2010) Arsenic as a Food Chain Contaminant: Mechanisms of Plant Uptake and Metabolism and Mitigation Strategies. Ann Rev Plant Biol 61:535-559

Zhen YH, Cheng YJ, Pan GX, Li LQ (2008) Cd, Zn and Se Content of the Polished Rice Samples from Some Chinese Open Markets and Their Relevance to Food Safety. J Saf Environ 8:119-122

Zhu HH, Chen C, Zhu QH, Huang DY (2016) Effects of Soil Acidification and Liming on the Phytoavailability of Cadmium in Paddy Soils of Central Subtropical China. Environ Pollut 219:99-106

Zhu YG, Sun GX, Lei M, Teng M, Liu YX, Chen NC, Wang LH, Carey AM, Deacon C, Raab A, Meharg AA, Williams PN (2008) High Percentage Inorganic Arsenic Content of Mining Impacted and Nonimpacted Chinese Rice. Environ Sci Technol 42(13):5008-5013

\section{Submit your manuscript to a SpringerOpen ${ }^{\mathcal{O}}$ journal and benefit from:}

- Convenient online submission

- Rigorous peer review

- Immediate publication on acceptance

- Open access: articles freely available online

- High visibility within the field

- Retaining the copyright to your article

Submit your next manuscript at springeropen.com 